\title{
Radionuclide speciation in sediments of the Yenisei River
}

\author{
A. Bolsunovsky \\ Institute of Biophysics Siberian Branch Russian Academy of Sciences, 660036 Krasnoyarsk, \\ Russia
}

\begin{abstract}
The examination of sediment samples collected from the Yenisei River revealed the presence of artificial radionuclides characteristic of radioactive discharges from the MCC facility: isotopes of europium $\left({ }^{152} \mathrm{Eu},{ }^{154} \mathrm{Eu}\right.$, and $\left.{ }^{155} \mathrm{Eu}\right)$, cesium $\left({ }^{137} \mathrm{Cs}\right.$ and $\left.{ }^{134} \mathrm{Cs}\right),{ }^{60} \mathrm{Co},{ }^{90} \mathrm{Sr}$, and transuranium elements. Radionuclide concentrations in sediment layers remained high as far as $240 \mathrm{~km}$ downstream of the MCC. The vertical distribution of radionuclides in sediment cores was very complex, and down-core variations were due to different amounts of radionuclides released by the MCC and due to variations in the hydrologic conditions in the river. Sequential extraction performed on samples of the upper layers of the sediment core showed different degrees of potential environmental availability of artificial radionuclides: the amounts of extracted ${ }^{90} \mathrm{Sr},{ }^{152} \mathrm{Eu}$ and ${ }^{241} \mathrm{Am}$ were the largest $\left(60-80 \%\right.$ of initial activity), then followed ${ }^{60} \mathrm{Co}(30 \%),{ }^{238,239,240} \mathrm{Pu}$ (15-30\%), and, last, ${ }^{137} \mathrm{Cs}(5-15 \%)$. The distribution of ${ }^{238} \mathrm{U}$ among chemical fractions of sediments was similar to that of ${ }^{60} \mathrm{Co}$ and ${ }^{238,239,240} \mathrm{Pu}: 30-40 \%$ of ${ }^{238} \mathrm{U}$ initial activity was extracted. In a few samples,

${ }^{241} \mathrm{Am}$ was present in the unextractable form, which may be accounted for by the presence of microparticles of the reactor fuel.
\end{abstract}

\section{INTRODUCTION}

The Yenisei is one of the world's largest rivers, over $4000 \mathrm{~km}$ long, flowing into the Kara Sea. The Mining-and-Chemical Combine (MCC), which has been producing weapons-grade plutonium since 1958, is situated on the east bank of the Yenisei River, $60 \mathrm{~km}$ down of the city of Krasnoyarsk. The MCC has been in operation for many years, contaminating the Yenisei River basin with radionuclides [1-7]. Previously levels of artificial radionuclides were mostly measured in samples of the floodplain soils; just several measurements have been done in sediments [2, 4-7]. To study the migration of artificial radionuclides and their bioavailability it is necessary to have information on the physicochemical forms of radionuclides in sediments.

The aim of this study was to assess the activity concentrations of artificial radionuclides and the strength of their binding in sediments of the Yenisei River.

\section{MATERIALS AND METHODS}

During the expeditions of 1997-2010, samples of sediment were collected from the Yenisei River in the two main areas: near the MCC (site E15, near the village of - B. Balchug, $96 \mathrm{~km}$ downstream of Krasnoyarsk) and at a considerable distance downstream (site E18 - near the village of Zakharovka and site E20-K - near the village of Kargino, 280 and $320 \mathrm{~km}$ downstream of Krasnoyarsk, respectively) (Fig. 1). The village of B. Balchug is situated about $15 \mathrm{~km}$ downstream of where the MCC releases its radioactive water. For comparison purposes, we also collected sediment cores at a position upstream of the MCC, near the village of Esaulovo (site E5, $45 \mathrm{~km}$ downstream of Krasnoyarsk) (Fig. 1). The diameter of the corer was $11 \mathrm{~cm}$ and it collected cores up to $1.5 \mathrm{~m}$ long. Cores were sectioned into $3-\mathrm{cm}$ thick layers, except for the top sediment layer, which was 5 to $10 \mathrm{~cm}$ thick (depending on the core moisture content). The maximum number of layers for a core was 46 . 


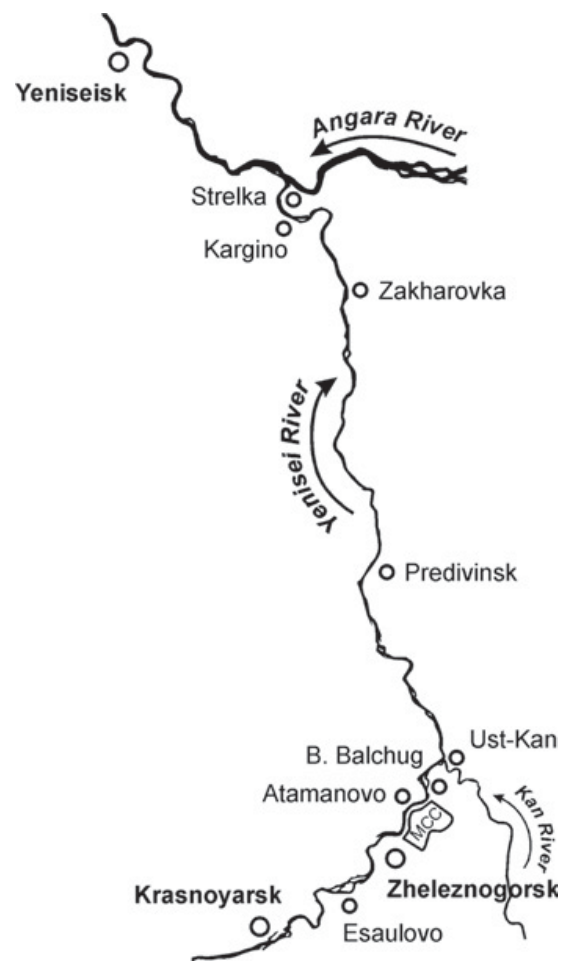

Figure 1. Map of the south of the Krasnoyarskii Krai (Russia), showing the MCC facility and settlements near where sediment samples were collected. Scale $1: 2800000$.

Measurements of activity concentrations of $\gamma$-emitting nuclides (including ${ }^{241} \mathrm{Am}$ ) were conducted at the Institute of Biophysics SB RAS using a Canberra $\gamma$-spectrometer (USA) coupled to a GX2320 23\% hyperpure germanium (HPGe) coaxial detector. Gamma-spectra were processed using the CANBERRA GENIE-2000 software (USA). Radiochemical determination of actinides $\left({ }^{238,239,240} \mathrm{Pu},{ }^{241} \mathrm{Pu},{ }^{241} \mathrm{Am}\right.$, ${ }^{243,244} \mathrm{Cm}$ ) in sediment was performed at the RPA RADON (Moscow) [2, 4]. Activity concentrations of radionuclides in sediment layers were decay corrected to the sample collection dates. Concentration of ${ }^{238} \mathrm{U}$ in sediment samples was determined by neutron activation analysis. Binding of artificial radionuclides to sediment samples was examined using sequential extraction technique proposed by Tessier [8] and modified by Klemt and his colleagues [5, 6].

\section{RESULTS AND CONCLUSION}

\subsection{Levels of artificial radionuclides in sediments of different river sections}

A large number of sediment cores, some of them $142 \mathrm{~cm}$ long (containing 46 layers), were collected during expeditions to the Yenisei River. Gamma-spectrometry measurements showed artificial radionuclides typical of the radioactive discharge from the MCC: isotopes of europium $\left({ }^{152} \mathrm{Eu},{ }^{154} \mathrm{Eu}\right.$, and ${ }^{155} \mathrm{Eu}$ ), cesium $\left({ }^{137} \mathrm{Cs}\right.$ and $\left.{ }^{134} \mathrm{Cs}\right),{ }^{60} \mathrm{Co}$, and the transuranium element ${ }^{241} \mathrm{Am}$. The vertical distribution of radionuclides in the sediment cores is complex and there are several concentration minimums and maximums due to different amounts of radionuclides released by the MCC and due to variations in the hydrologic conditions in the river. Since 1997, we have collected sediment samples from the same position at the Yenisei River branch near the MCC at site E15. The maximum ${ }^{137} \mathrm{Cs}$ activity concentrations (up to $2000 \mathrm{~Bq} / \mathrm{kg}$ ) were registered in the middle and lower sections of the E15 
core. Gamma-spectrometric analysis also revealed very high ${ }^{241} \mathrm{Am}$ concentrations (up to $240 \mathrm{~Bq} / \mathrm{kg}$ ) in the middle and lower sections of the core, although the location of the peaks in the middle section of the core differ for two radionuclides. We also collected sediment cores at the village of Zakharovka, $200 \mathrm{~km}$ downstream of the $\mathrm{MCC}-$ at site E18. The maximum of ${ }^{137} \mathrm{Cs}$ activity concentration (up to 1400 $\mathrm{Bq} / \mathrm{kg}$ ) is registered in the lower part. Gamma-spectrometric analysis of the E18 core samples registered ${ }^{241} \mathrm{Am}$ (up to $170 \mathrm{~Bq} / \mathrm{kg}$ ) in the layers containing maximal levels of ${ }^{137} \mathrm{Cs}$ activity. For the sediment core collected at site E20-K, the maximum ${ }^{137} \mathrm{Cs}$ activity concentrations (up to $1400 \mathrm{~Bq} / \mathrm{kg}$ ) were recorded in the upper and the lower parts, with relatively low concentrations at the surface. ${ }^{241} \mathrm{Am}$ (up to $70 \mathrm{~Bq} / \mathrm{kg}$ ) was also detected in core E20-K.

The fact that some sediment layers contained abnormally high ${ }^{241} \mathrm{Am}$ concentrations could be indicative of abnormally high concentrations of other transuranium elements. Our further research was focused on radiochemical investigations of the sediment layers that, as registered by $\gamma$-spectrometry, contained maximal levels of radionuclides, including ${ }^{241} \mathrm{Am}$. Radiochemical investigations of the Yenisei River sediment samples revealed local anomalous spots with high activity concentrations of transuranium elements $\left({ }^{239,240} \mathrm{Pu}\right.$ and $\left.{ }^{241} \mathrm{Am}\right)$, which were 100 times higher than their global fallout levels. Results of our previous measurements of transuranium elements such as ${ }^{241} \mathrm{Pu}$ and ${ }^{237} \mathrm{~Np}$ in sediments show that their levels remain high even at a distance of $200 \mathrm{~km}$ downstream of the MCC [2]. The highest level of ${ }^{243,244} \mathrm{Cm}$ isotopes registered in the sediment of the Yenisei River is $21 \mathrm{~Bq} / \mathrm{kg}$ dry mass [4], which is more than twice higher than maximum curium levels reported for soils sampled not far from the Chernobyl Nuclear Plant. The presence of sediment layers containing abnormally high actinide levels [2, 4-7] can be indicative both of mobile behavior of transuranium radionuclides in the river ecosystem and of continued disposals of artificial radionuclides by the MCC. In layers of sediment cores collected at a position upstream of the $\mathrm{MCC}$, the level of ${ }^{137} \mathrm{Cs}$ (up to $16 \mathrm{~Bq} / \mathrm{kg}$ dry mass) can be accepted as the background value of radioactive contamination of sediments in this section of the Yenisei, due to global fallouts of ${ }^{137} \mathrm{Cs}$. In addition to artificial radionuclides, MCC effluents contain uranium isotopes. Our results suggest that upstream of the MCC, at the city of Krasnoyarsk and the village of Esaulovo, the average ${ }^{238} \mathrm{U}$ concentration in sediments is about $3.0 \mathrm{mg} / \mathrm{kg}$ dry mass. In sediments collected at the place where the $\mathrm{MCC}$ releases its radioactive water (at the villages of Atamanovo and B.Balchug), ${ }^{238} \mathrm{U}$ concentration is 1.5 times higher, reaching $4-5 \mathrm{mg} / \mathrm{kg}$. In some tributaries of the Yenisei River, close to Rosatom facilities, the highest ${ }^{238} \mathrm{U}$ concentrations in sediment layers amount to $6 \mathrm{mg} / \mathrm{kg}$.

\subsection{Radionuclide speciation in sediments of the Yenisei River}

Sequential extraction techniques are the most common method of studying radionuclide speciation in soils and sediments. Sequential extraction performed on samples of the upper layers of the sediment core collected near the MCC showed (Fig. 2) that the amounts of extracted ${ }^{90} \mathrm{Sr},{ }^{152} \mathrm{Eu}$ and ${ }^{241} \mathrm{Am}$ were the largest (60-80\% of initial activity), then followed ${ }^{60} \mathrm{Co}(30 \%),{ }^{238,239,240} \mathrm{Pu}(15-30 \%)$, and, last, ${ }^{137} \mathrm{Cs}(5-15 \%)$. The distribution of ${ }^{238} \mathrm{U}$ among chemical fractions of sediments was similar to those of ${ }^{60} \mathrm{Co}$ and ${ }^{238,239,240} \mathrm{Pu}: 30-40 \%$ of ${ }^{238} \mathrm{U}$ initial activity was extracted. The largest amounts of the radionuclides were extracted from such fractions as organic matter (Fraction IV) and oxides and hydroxides of iron and manganese (Fraction III). In a few samples, ${ }^{241} \mathrm{Am}$ was present in the unextractable form, which may be accounted for by the presence of microparticles of the reactor fuel. Assessment of potential environmental availability of artificial radionuclides in the analyzed sediments from the Yenisei River was based on the data for the first four fractions (Exchangeable Ions, Carbonates, Oxides and Hydroxides of Iron and Manganese, and Organic Matter) of sequential extraction. Based on our results (Fig. 2), we arranged radionuclides in the following sequence, showing their relative mobility in the upper layers of the cores:

$$
{ }^{90} \mathbf{S r} \approx{ }^{241} \mathbf{A m} \approx{ }^{152} \mathbf{E u}>{ }^{60} \mathbf{C o} \approx{ }^{238} \mathbf{U} \approx{ }^{239 / 240} \mathbf{P u}>{ }^{137} \mathbf{C s} .
$$




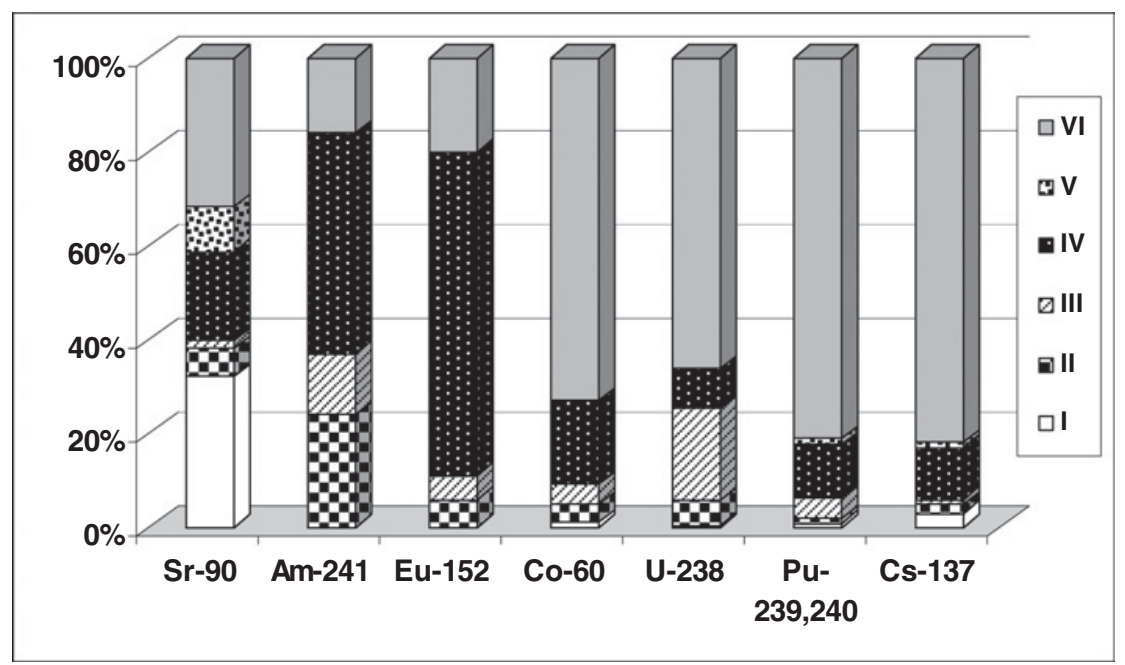

Figure 2. Typical distribution of radionuclide activities among chemical fractions of the upper layers of the sediment collected near the MCC. Fractions: I - Exchangeable Ions; II - Carbonates; III - Oxides and Hydroxides of Iron and Manganese; IV - Organic Matter; V - Amorphous silicates; VI - Residuals.

The results of sequential extraction of sediment samples showed differences in radionuclide concentrations in extracted forms between the lower and the upper sediment layers of the core. These data suggest that the physicochemical processes occurring in the lower sediment layers change the properties of the sediments and their adsorption power. The amounts of the radionuclides released from different fractions varied depending on the distance downstream of the MCC. Previously, similar studies were only performed for 1 or 2 radionuclides [7]. This study is the first to assess potential environmental availability of a large number of radionuclides (including transuranic ones) in sediments, taking into account different residence times of radionuclides in sediment layers (based on layer dating).

\section{Acknowledgments}

The study was partly supported by RFBR Grant No 09-05-00129 and Integration Project SB RAS No 1.

\section{References}

[1] Vakulovsky, S.M., Kryshev I.I., Nikitin A.I., et al., J. Environ. Radioactivity, 29 (1995) 225-236.

[2] Bolsunovsky, A. and L. Bondareva, Journal of Alloys and Compounds, 444-445 (2007) 495-499.

[3] Bolsunovsky, A., Aquatic Ecology, 38 (2004) 57-62.

[4] Bolsunovsky, A., Ermakov, A. and Sobolev, A., Radiochim. Acta, 95 (2007) 547-552.

[5] Klemt, E., Spasova, Y., Zibold, G., Bolsunovsky, A. In: Per Strand, Torun Jolle and Ase Sand (eds) Environmental Radioactivity in the Arctic \& Antarctic. Norwegian Radiation Protection Authority, Norway, (2002) pp. 67-70.

[6] Semizhon, T., Röllin S., Spasova Y., Klemt E., J. Environ. Radioactivity, 101 (2010) 385-402.

[7] Skipperud, L., Brown, J., Fifield, L.K. et al., J. Environ. Radioactivity, 100 (2009) 290-300.

[8] Tessier, A., Campbell, P.G.C. and Bisson, M., Analytical Chemistry, 51 (1979) 844-851. 